\title{
Health Education Mentoring on Sadar Seimbang Nutrisi (SSN) and The Dangers of Anemia through Student Empowerment Movements with Examination of Hematology (Hemoglobin-Hematocrit) in Vocational High School and Junior High School-As-Syarief Garut for Mountainous Area Community
}

\author{
Sitti Syabariyah ${ }^{a}$, Retno Anesti ${ }^{\mathrm{b}}$, Alya Nurhalizac), Wika Puspika Sarid), and Rekha \\ Rahmanilahe) \\ Nursing Study Program, Sekolah Tinggi Ilmu Kesehatan 'Aisyiyah Bandung, Bandung, Indonesia \\ a)Corresponding author: sittisyabariyah@gmail.com \\ b)retnoanesti@gmail.com \\ c)nersnurhaliza@gmail.com \\ d)wikap1904@gmail.com \\ e)rekharahmanilah@gmail.com
}

\begin{abstract}
Anemia in adolescent girls still shows a high prevalence rate. The prevalence of anemia in Indonesia at the age of $5-14$ is $26.4 \%, 18.4 \%$ of patients aged $15-24$ years, and women have a high risk of anemia, especially in adolescent girls. Adolescent girls with anemia will have changed the menstrual cycle. The importance of learning adolescent nutritional status will be strategic planning for decreased nutritional macro and micro deficiencies in women. This community dedication aimed to present information about the risk of anemia through student empowerment and hematological examination (hemoglobinhematocrit). A piece of good and proper knowledge about balanced Nutrition is an essential point of anemia prevention in adolescents.
\end{abstract}

Keywords: Adolescent; anemia; awareness of nutrition; malnutrition; the growth spurt

\section{INTRODUCTION}

The influence of Nutrition through the life cycle will have a significant short-term and long-term impact on the quality of human resources. Therefore, it is essential to study the nutritional status of adolescents to help plan strategies to combat nutritional deficiencies, both macro and micro, including in adolescent girls as future mothers.

Lack of macro and micronutrients can cause weight loss and anemia. Anemia in adolescent girls is still high, with the prevalence of anemia in the world from $40-88 \%$ (World Health Organization, 2013). The total population of adolescents (10-19 years) in Indonesia is $26.2 \%$, consisting of $50.9 \%$ male and $49.1 \%$ female (Kemenkes RI, 2013). Based on Riskesdas data in 2013 , the prevalence of anemia in Indonesia is $21.7 \%$, with anemia sufferers aged 5-14 years at $26.4 \%$ and $18.4 \%$ in patients aged $15-24$ years. Women have the highest risk of developing anemia, especially in adolescents (Kemenkes RI, 2015).

A woman with anemia will experience changes in her menstrual cycle. Adequate hemoglobin levels or a person without anemia will help regularize the menstrual cycle in women. Otherwise, if there is a lack of iron in the body, it will cause low hemoglobin levels, which will lead to further complications..

Undang-undang nomor 36 tahun 2009 considering about health in Indonesia, precisely chapter number 141 on Nutrition, which contains that efforts for improving public Nutrition aimed at improving the nutritional quality of individuals and communities, among improving dietary habit, improving nutrition awareness behavior and increasing access to quality nutrition services and health in accordance with advances in science and technology.

One attempt to develop about Nutrition by the government with the continuously through socialization, especially knowledge awareness for young women and adolescent about Nutrition, consuming iron tablets and the knowledge about dangers of anemia. The purpose of giving blood 
tablets is one of the efforts to fulfill iron for young women as a reserve of iron in the body for preparing a healthy and robust human generation in the future.

College of Health Sciences (STIKes) 'Aisyiyah Bandung is one of the educational institutions with qualified human resources teaching staff and aims to produce competent health workers. Most of the students who attend lectures at this institution came from Bandung Regency. The contribution of STIKes to the surrounding community (in particular) and West Java (in general) is necessary to carry out as part of the Tri Dharma of Higher Education, namely Community Service. The form of service carried out collaborates with the Regional Leadership of 'Aisyiyah (PDA) Bandung Regency by forming Qaryah Thayyibah.

As-Syarief Garut Islamic Junior High School (SMP) and Vocational High School (SMK) are Islamic educational institutions owned by the As-Syariefiyah Foundation, Karang Tengah District, Garut Regency. The socialization of health education rarely touches the school's location in a remote mountainous area from the District Health Office, let alone the Province. However, positive values were found in the education and learning process in the Asy-Syarief Islamic Junior High School and Vocational School which could be potential to empower their students because of the development of the Four Pillars of Education, namely: learning to know, creative action according to the environment (learning to do), participation and cooperation (learning to live together) and improving personality and responsibility development (learning to be).

Based on school health unit (UKS) data and student health reports by the Principal of SMP/ SMK Islam Asy-Syarief, there were several cases of female students with complaints of frequent dizziness, pale skin and weakness, sometimes in some conditions, such as during ceremonial activities, some students fainted. Another problem that was studied during the initial screening was the number of students who snacked more and consumed fast foods that were not contain balanced Nutrition than, breakfast and eating healthy food from home. This causes problems in the student's condition, both in nutritional status and in the presence of several health problems such as anemia in adolescents.

\section{METHOD}

This community service activity is carried out in 2 stages, the stages are counseling on awareness of balanced Nutrition/ sadar seimbang nutrisi (SSN) and the dangers of anemia in adolescents, including the understanding of SSN, the benefits of SSN for adolescents, the dangers of unbalanced nutrition, the understanding of anemia, anemia prevention, signs and symptoms of anemia, complications of anemia, how to prevent it. Counseling gives by coordinator community service in collaboration with student college members and school health unit (UKS) team, School Principals, School Committees using extension media such as powerpoints, flipcharts, leaflets, and videos. Hematologic parameters are performed by checking $\mathrm{Hb}$ (hemoglobin), hematocrit (hematocrit), and optometry students. Preparation of activities, including coordination activities with SMP and SMK As Syaief, Karang Tengah district, Kabupaten Garut. Preparation of tools and materials and accommodation; and preparation of places to implement health education (counseling) through coordination with schools and health centers/ Puskesmas in Karang Tengah district.

Health education counseling or mentoring activities as well as Haematology parameter examination, including: anthropometric and HB-Ht examination. The initial screening assists UKS staff on students according to the calculation of the number of samples with the total sampling technique. The population is homogeneous, so a larger sample size of 189 students obtains.. First entered to the As-Syarief Hall; the opening and introduction to the As Syarief SMP-SMK students who were the targets of the activity, previously opened with remarks from school representatives and UKS officers; Counseling begins with Conscious Balanced Nutrition/ Sadar Seimbang Nutrisi (SSN), then continues with presenting about anemia and the last stage is $\mathrm{Hb}-\mathrm{Ht}$ examination. The outreach activities intersperse with ice breaking and video screenings containing a discussion of anemia; and discussion/question-and-answer sessions with participants. Participants seemed enthusiastic in participating in the activity. The last sessions for this activity included giving 
souvenirs to each participant and providing input on the results for the school committee and health workers.

\section{RESULTS}

This activity collaborates with the College of Health Sciences (STIKes) 'Aisyiyah Bandung with the School Committee of junior high school and vocational high school As Syarief Garut and the Sub-district Health Center Karang Tengah, Garut Regency. This activity attends by 189 students in grades 7-9 junior high school and 10-12 vocational high school students. In general, health education activities (counseling) regarding SSN and Anemia can run smoothly. This health education program initiated at As-Syarief junior high schools will be roadshows to other schools in Garut Regency, other villages, and Garut City.

The school, especially the principal, appreciated this activity. The general public and especially teenagers need health education regarding awareness of consuming balanced Nutrition and the dangers of anemia, which can cause unwanted risk in women's reproductive years later. The school carries preparation for the place before counseling starts, the excecutors (consisting of STIKes 'Aisyiyah team and UKS staff from As-Syarief Garut) first conduct screening by interviewing students followed by counseling, examination and distribution of leaflets according to the number of sample calculations with the total sampling technique, previously the acceptance of the community dedication team was held by ceremony in the school field.

After all, students are ready in the school hall; counseling open. In the core activity, the speaker explained about awareness of balanced Nutrition (SSN) and the dangers of Anemia in Adolescents, including the understanding of SSN, the benefits of SSN for adolescents, the dangers of unbalanced Nutrition, the definition of anemia, prevention of anemia, signs, and symptoms of anemia, complications of anemia, and how to prevent the anemia. Participants were evaluated through questions to see the extent of understanding related to the material provided. Then examined hematological parameters are done by checking hemoglobin and hematocrit levels and measured anthropometric all students. Proper health information about balanced Nutrition is one of the critical points to prevent malnutrition in adolescents One of the factors that can influence a teenager to develop optimally is nutritional intake.

\section{DISCUSSION}

Balanced nutritional intake will support good physical growth, especially hormonal, mental, cognitive, and positive behavior in adolescents. The balanced nutritional intake contains composition balanced nutrition, avoiding nutrients with the type and amount according to the body's needs, gender, age, and health status. Mustafa, et al (2019) stated that respondents' knowledge increased after an intervention about lifestyle and anemia. The intervention gives by health education about the functioning of the food for healthy, and nutrition needed for the function of the body to optimizing in the condition of deficiency or excess intake, the importance of balanced nutrition and dietary intake as protein and iron in particular to increase the level of hemoglobin in a teenage girl.

Oddo, et al (2018) said that providing additional nutrition to adolescent girls, such as giving iron supplements or multivitamins, can prevent anemia in adolescent girls; usually, this activity is carried out through school socialization. In addition, nutritional intake such as the types of micronutrients found in primary vegetables can prevent anemia, such as young women in the West Java area who consume green leafy vegetables, which are one type of food to prevent anemia. However, few know that animal protein is also essential in preventing anemia (Agustina, 2016).

Anemia still has become a public health problem throughout the world. In particular, the prevalence of anemia in school-age children and adolescents has nearly tripled. National health surveys also show that the prevalence of anemia is higher in rural than in urban areas. Iron deficiency is the most common micronutrient deficiency in the world. Indonesia is a developing country (a low to middle-income country), with the population still living in poverty, and poverty is the root cause of malnutrition (Andriastuti M and IImana G, 2019) 
To reduce the number of anemia sufferers in adolescents, the fulfillment of nutrition and balanced nutrition in adolescents must be considered. Several interventions that government programs have carried out are nutritional interventions based on the balanced nutrition guidelines of the Indonesian Health Ministry, which contain a variety of balanced nutrition menus, maintaining personal hygiene, and doing physical activity. Efforts to foster and other nutritional interventions are carried out by the government gradually and continuously, namely by giving blood-added tablets for young women (Kemenkes RI, 2015). The iron tablet program is one of the efforts to fulfill iron for young women as a reserve of iron in the body to prepare a healthy, quality, and product generation for the future.

Therefore, critical attention is needed, especially for the nutritional status of the adolescent group; this is related to the period when adolescents begin to experience the peak of their growth age (Berheto, 2017). At adolescence, this incident can affect especially young women aged 1019 years, especially having a risk of iron deficiency due to blood loss during menstruation. And maternal metabolism during pregnancy (Aryani, 2018; Diaris, 2019; Widjaja R, 2014)

The effects of nutrition throughout the life cycle will have significant economic and socially significant short-term and long-term benefits. Therefore, it is essential to study the nutritional status of adolescents to help plan strategies to burn off macro and micro nutritional deficiencies for the future, including future mothers. The nutrition needed by adolescents usually adjusts to the amount of energy expended, especially as time goes on, adolescent activities will continue to increase, therefore the need for additional energy intake from carbohydrates, as well as types of protein that can play a role in the formation of muscle mass, as well as other micro nutrients (calcium in bone formation, iron as a support in the formation of hemoglobin and especially affects the menstrual cycle of adolescent girls, folic acid, vitamins A, D, E and B6) (Corkins, 2016).

Many factors caused adolescent girls to have a poor nutritional status, such as the frequency of breakfast intake that is rarely done, socioeconomic factors such as maternal education, a distance of residence, and poor hygiene behavior (Berheto, 2017). Adolescents with low socioeconomic status are more prone to iron deficiency. The lack of low iron intake and foods low in iron content will exacerbate chronic blood loss due to menstruation and iron malabsorption (Andriastuti and IImana, 2019; Shyama, 2016). Iron deficiency can affect motor and cognitive abilities and cause behavioral disorders in adolescents that may be difficult to change. Iron deficiency and anemia in adolescents also have various consequences: impaired growth, physical and mental development, decreased physical fitness, and school performance. Therefore, it is essential to detect and screen for iron deficiency (Andriastuti and IImana, 2019)

\section{CONCLUSIONS AND RECOMMENDATIONS}

Giving knowledge about preventing malnutrition in adolescents is very important because one of the factors that can influence a teenager to develop optimally is inadequate nutritional intake. A balanced nutritional intake will support good physical growth, especially hormonal, mental, cognitive, and positive behavior in adolescents. The balanced nutritional intake contains composition balanced nutrition, avoiding nutrients with the type and amount by the body's needs, gender, age, and health status.

Providing additional nutrition for adolescent girls, such as the iron tablet program or giving multivitamins, can prevent anemia in young women; usually, health education mentoring is carried out through socialization in schools. In addition, nutritional intake such as the types of micronutrients found in vegetables can prevent anemia, such as young women in West Java who has the habit of consuming green leafy vegetables which are one type of food to prevent anemia, it is important for prevention of anemia.

There are efforts to develop and other nutritional interventions carried out by the government gradually and continuously, namely by giving blood-added tablets for young women. The iron tablet program is one of the efforts to fulfill iron for young women as a reserve of iron in the body to prepare a healthy, quality, and product generation for the future. Therefore, special attention is needed, especially on the nutritional status of the adolescent group; this is related to the period when adolescents begin to experience the peak of their growing age. 
Based on the results and evaluation from this program already reached the target, the School (Principal and Teacher Council), UKS Officers, Community Health Centers, and Villages appreciate the community program and expect similar activities to be carried out regularly in SMPSMK and can expand to all Karang Tengah sub-districts. We hope this program can disseminate helpful health information for students, adolescent girls, and the community.

\section{ACKNOWLEDGMENTS}

We express our gratitude to Allah Subhanahu Waata'ala, because for the facilities provided so that this community service can run smoothly. This community service can be carried out well with the all support of (1) Sekolah Tinggi Ilmu Kesehatan 'Aisyiyah Bandung, (2) Scool Comitte and all of teacher SMP-SMK As Syarief Garut, (3) Head and all staff of PUSTU (Puskesmas Pembantu) Karang Tengah district, Kabupaten Garut, (4) The greatest students of SMP-SMK As Syarief Garut. May Allah Subhanahu Waata'ala reward you with the good you deserve. Amen.

\section{REFERENCES}

Agustina, R. (2016). Formative Reasearch for An Improved Iron Folic Acid Suplementation Program for School Going Adolescent in West Java Province.

Andriastuti M, Ilmana G, A. S. (2019). International Journal of Pediatrics and Prevalence of anemia and iron profile among children and adolescent with low socio-economic status. International Journal of Pediatrics Adolescent Med. https://doi.org/https://doi.org/10.1016/j.ijpam.2019.11.001

Andriastuti M, IImana G, Avilia S. (2019). International Journal of Pediatrics and Prevalence of anemia and iron profile among children and adolescent with low socio-economic status. International Journal of Pediatrics Adolescent Med. https://doi.org/https://doi.org/10.1016/j.ijpam.2019.11.001

Aryani. (2018). Menstrual cycle patterns of Indonesian adolescents. Paediatrica Indonesiana, 58(3), 101. https://doi.org/http://dx.doi.org/10.14238/pi58.3.2018.101-5

Berheto, T. M. (2017). Predictors of nutritional status among adolescent school girls in Southwest Ethiopia. International Journal of Nutrition and Metabolism, Vol. 9(1),(2141-2332), 1-9. https://doi.org/10.5897/IJNAM2016.0209

Corkins, M. R. (2016). Nutrition in Children and Adolescents. Elsevier-Medical Theclinics N Am, 1217-1235. https://doi.org/http://dx.doi.org/10.1016/j.mcna.2016.06.005

Diaris. (2019). THE DESCRIPTION AGE AT MENARCHE AND PREPARATION FOR MENSTRUATION OF CHILDREN AGED BETWEEN 10-11 YEARS. Universitas Udayana, 221223.

Kemenkes RI. (2015). Riset Kesehatan Dasar (RISKESDAS). Jakarta.

Mustafa, A. dkk. (2019). The Effectiveness of Nutrition Education about Local Specific Food-based Balanced Nutrition Recommendation on Dietry Intake Level and Anemia Status in Female Adolscents at the Hidayatullah Arrohmah Islamic Boarding School Malang. The First International Conference on Health Profession.

Oddo, M. et al. (2018). Potential interventions targeting adolescent nutrition in Indonesia: a literature review. Public Health Nutrition, 22 (1), 15-27.

Shyama, C. et all. (2016). Urban Rural Comparison of Antrhtopometry and Menarcheal Status od Adolescent School Going Girls of Jodhpur Rajasthan, India. Journal of Clinical and Diagnostic Reserach, 10.

Widjaja R, I. (2014). Anemia among children and adolescent in a rural area. Paediatrica Indonesiana, 54 No. 2.

World Health Organization. (2013). The Global Prevalence Of Anemia In 2011. Geneva: World Health Organization. 


\section{APPENDIX}

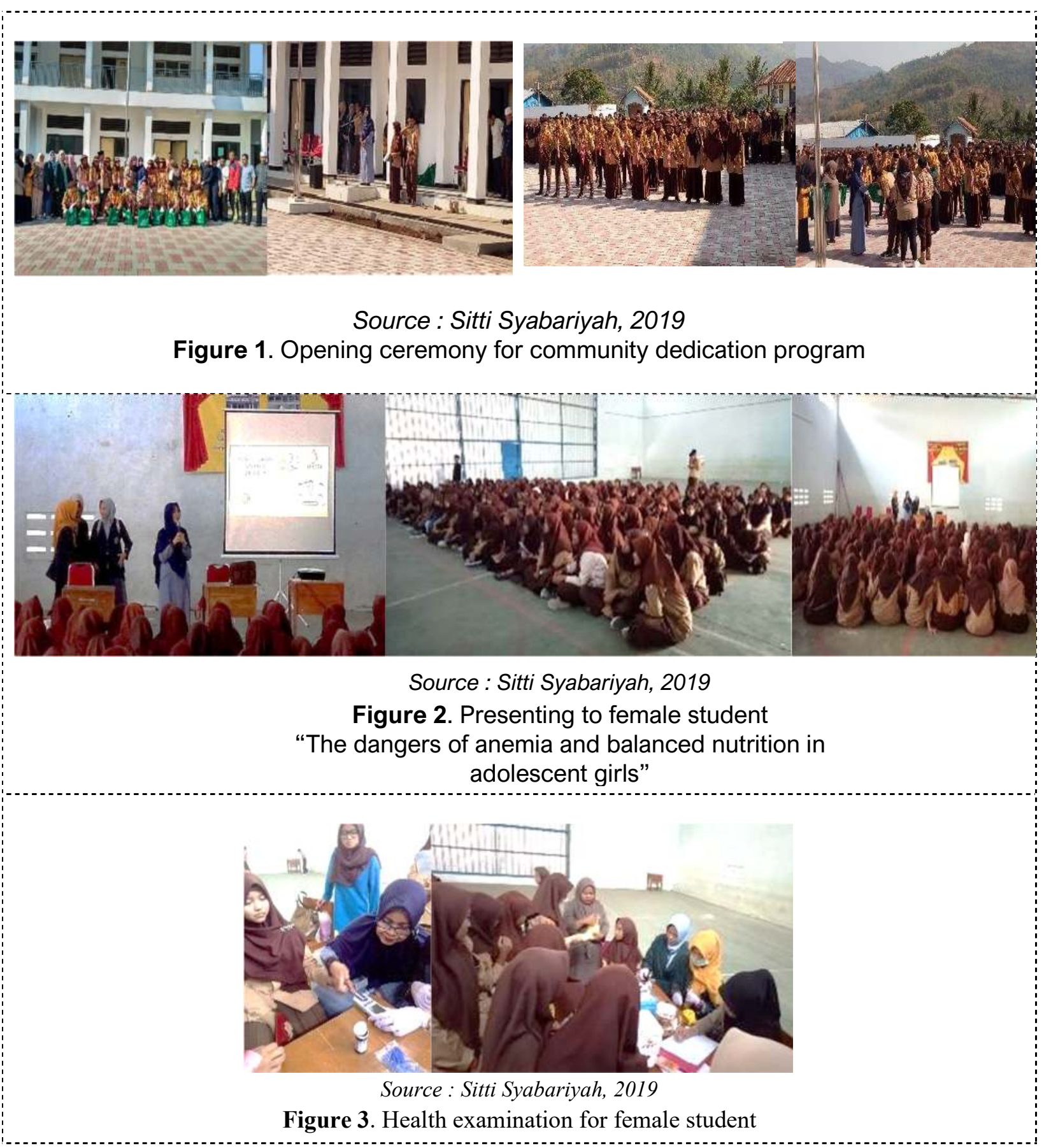

